\title{
SELEKTIVITAS JARING ARAD (MINI BOTTOM TRAWL) YANG DILENGKAPI JTEDs TERHADAP IKAN BELOSO (Saurida sp.)
}

\author{
Hufiadi dan Mahiswara \\ Peneliti pada Balai Riset Perikanan Laut, Muara Baru-Jakarta \\ Teregistrasi I tanggal: 10 Agustus 2009; Diterima setelah perbaikan tanggal: 20 Agustus 2009; \\ Disetujui terbit tanggal: 9 Nopember 2009
}

\begin{abstract}
ABSTRAK
Hasil tangkapan sampingan dan tertangkapnya ikan target di bawah ukuran sebagai akibat dari penggunaan alat tangkap non selektif telah menjadi permasalahan dunia pada akhir dekade ini. Upaya konservasi ikan target di bawah ukuran dan hasil tangkapan sampingan melalui peningkatan selektivitas alat tangkap merupakan bagian dari code of conduct for responsible fishing yang telah dicanangkan oleh FAO. Perikanan arad yang berkembang di perairan utara Jawa merupakan alat tangkap yang efektif dalam memanfaatkan sumber daya ikan demersal. Permasalahan utama pada perikanan ini adalah banyaknya jumlah hasil tangkap sampingan berukuran kecil yang belum layak tangkap. Dalam upaya untuk mengurangi tangkapan ikan muda yang belum layak tangkap telah dilakukan observasi dan uji coba operasi penangkapan melalui penggunaan perangkat JTEDs pada alat tangkap arad yang digunakan nelayan Pekalongan. Perangkat JTEDs yang digunakan dibedakan pada ukuran jarak antar kisi-kisi, yaitu 10,0, 17,5, dan 25,4 mm. Analisis selektivitas kisi menggunakan model kurva logistik dengan bantuan solver pada Microsoft Excel. Hasil penelitian menunjukkan penggunaan JTEDs pada arad dapat meloloskan ikan beloso (Saurida sp.) ukuran kecil rata-rata berkisar 10,21-63,76\%. JTEDs dengan ukuran kisi-kisi 25,4 mm memiliki tingkat seleksi ikan beloso terbaik pada tingkat seleksi $50 \%\left(\mathrm{FL}_{50 \%}\right)$.
\end{abstract}

KATAKUNCl: JTEDs, arad, kisi-kisi, ikan beloso, selektivitas

\section{PENDAHULUAN}

Dalam pengoperasian jaring arad di samping udang sebagai sasaran penangkapan, tertangkap pula berbagai jenis ikan dan organisme dasar. juvenile dan trash fish seperti ubur-ubur, bintang laut, dan kekerangan yang ikut tertangkap traw/dan sejenisnya dibuang kembali ke laut dalam keadaan mati dan diistilahkan sebagai discards (buangan) dan buangan dapat berdampak buruk terhadap sumber daya dan lingkungan (Pascoe, 1997). Adapun juvenile dan trash fish yang tertangkap jaring arad tetap dimanfaatkan, namun tertangkapnya juvenile dapat berpengaruh pada penurunan sumber daya ikan secara cepat, karena belum sempat dewasa dan bertelur serta beranak untuk kepentingan recruitment.

Jaring traw/termasuk jaring arad dikenal sebagai alat tangkap yang menghasilkan hasil tangkapan sampingan lebih banyak dibandingkan alat tangkap lainnya. Hal ini dikarenakan mini trawlatau jaring arad menggunakan mata jaring bagian kantong (cod end) relatif kecil. Selain itu jaring arad dioperasikan dengan cara ditarik menyapu dasar perairan sehingga berbagai ikan dan biota lainnya ikut tertangkap. Alat tangkap trawl dan sejenisnya dioperasikan dengan cara ditarik dengan kecepatan dan waktu tertentu di sepanjang dasar perairan untuk menangkap ikan-ikan dasar (FAO, 1995).
Untuk menangani permasalahan pengurangan hasil tangkapan sampingan jaring arad maka salah satu solusi yaitu dengan cara memperkecil hasil tangkapan non target dan juvenil ikan melalui pemasangan alat penyaring ikan juvenile and trash exluder devices (JTEDs). JTEDs dipasang di bagian kantong jaring arad yang berfungsi untuk menyaring atau mengeluarkan juvenil dan ikan rucah yang bukan menjadi tujuan penangkapan. Tulisan ini menyajikan tingkat pelolosan jaring arad yang dipasang perangkat seleksi ikan JTEDs terhadap ikan beloso.

\section{BAHAN DAN METODE}

\section{Bahan Penelitian}

Penelitian ini dilakukan pada tahun 2005 di perairan Pekalongan. Data dan informasi terkait dengan aspek selektivitas jaring arad diperoleh melalui uji coba pengoperasian jaring arad (mini bottom traw) yang dilengkapi dengan alat pereduksi ikan muda dan rucah yang disebut JTEDs. JTEDs dipasang pada bagian antara badan dan kantong jaring (Gambar 1).

Kegiatan uji coba dilakukan dengan menggunakan kapal berdimensi panjang (LoA) 12,0 m, lebar (B) 3,5 $\mathrm{m}$, dan dalam (D) $0,8 \mathrm{~m}$ atau $10 \mathrm{GT}$, dengan mesin penggerak $22 \mathrm{HP}$. Kapal dilengkapi dengan jaring arad dengan ukuran tali ris atas (head rope) $12 \mathrm{~m}$, tali ris 


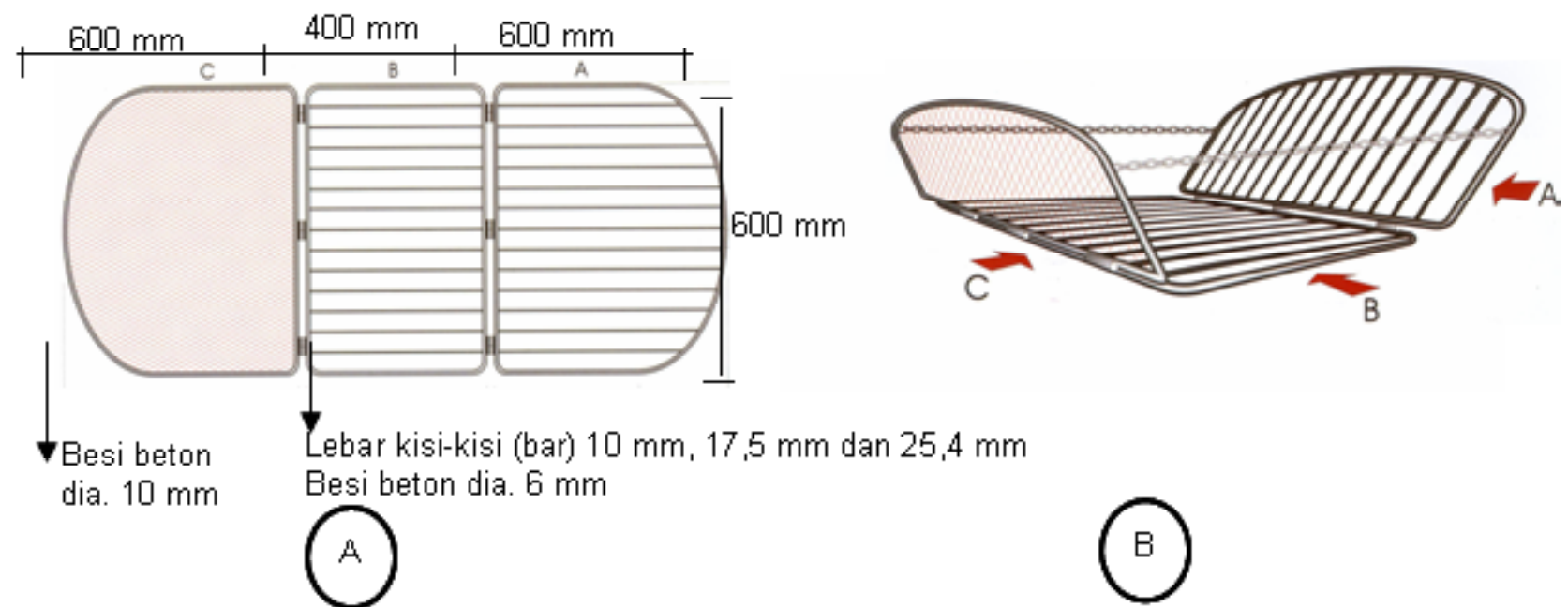

Gambar 1. A-B desain dan konstruksi JTEDs yang di uji coba.

bawah (ground rope) $14 \mathrm{~m}$, ukuran mata jaring bagian kantong 1 inci. Lokasi penangkapan pada kedalaman 20-30 m. Lama penarikan jaring rata-rata 1 jam dengan kecepatan kapal rata-rata 3 knot.

Pada uji coba ini digunakan tiga macam perlakuan. Perlakuan pertama adalah JTEDs dengan lebar kisikisi 10,0 mm, kedua 17,5 mm, dan ketiga 25,4 mm. Ketiga ukuran kisi-kisi JTEDs dipasang pada sebuah jaring arad dan dioperasikan secara bergantian. Keseluruhan pengoperasian 21 kali, masing-masing ukuran kisi kisi JTEDs $(10,0,17,5$, dan 25,4 mm) sebanyak 7 kali ulangan. Masing-masing hasil tangkapan, baik yang masuk ke dalam codend maupun cover net ditimbang secara total, diidentifikasi jenisnya dan dilakukan pengambilan contoh. Untuk bahan kajian selektivitas, ikan beloso yang tertangkap diukur panjang cagaknya (fork length), tinggi tubuh (body depth), dan lingkar tubuh (body girth). Identifikasi jenis ikan mengacu pada referensi Fischer \& Whitehead (1974).

\section{Analisis Data}

Tingkat kelolosan ikan yang tertangkap jaring arad yang dilengkapi JTEDs dihitung dengan menggunakan formula:

Tingkat pelolosan $(\%)=(\mathrm{W}$ cover net $\times 100) /(\mathrm{W}$ codend $+\mathrm{W}$ cover net) (1

di mana:

\footnotetext{
$W$ cover net $=$ bobot tangkapan $(\mathrm{kg})$ yang keluar (lolos) melalui JTEDs dan tertampung dalam cover net

$W$ codend = bobot tangkapan $(\mathrm{kg})$ yang masuk ke kantong jaring arad
}

Rasio pelolosan yang dikalkulasikan berdasarkan pada rasio tinggi tubuh (body depth) terhadap ukuran kisi-kisi diformulasikan:

$$
R_{t}=L / d
$$

di mana:

$$
\begin{aligned}
& \mathrm{R}_{\mathrm{t}}=\text { nilai rasio tinggi tubuh } \\
& \mathrm{L}=\text { tinggi tubuh (body depth) } \\
& \mathrm{d}=\text { kisi-kisi (grid space) }
\end{aligned}
$$

Analisis: $R_{t}>1$ : ikan tidak dapat lolos dari kisikisi

$R_{\mathrm{t}}<1$ : ikan dapat lolos melalui kisi-kisi

$R_{t}=1$ : ikan dapat lolos atau tidak melalui kisi-kisi

Model yang secara langsung dan digunakan untuk mengestimasi selektivitas alat tangkap yang diujicoba adalah dengan cara membandingkan ukuran panjang ikan (L) yang tertahan (masuk kantong jaring-codend) dan yang lolos melalui kisi-kisi JTEDs (tertampung di cover net). Kurva selektivitas jaring arad dengan JTEDs didekati dengan model logistik (logistic curve) dihitung dengan menggunakan rumus sebagai berikut (Sparre \& Venema, 1999):

$$
\Sigma(\lambda)=\frac{1}{\left[\left(1+\varepsilon \xi \pi\left(\alpha^{*} \lambda+\beta\right)\right]\right.}
$$

á dan â = parameter-parameter dari model logistik dihitung melalui pendekatan maximum likelihood method (Tokai, 1997)

$\mathrm{S}(\mathrm{I}) \quad$ = fungsi dari selektivitas JTEDs terhadap panjang ikan 
Untuk menentukan kemiringan dari kurva selektivitas (selection span) dihitung dengan rumus:

$\mathrm{SR}=-2 \ln (3) / a ́$ $(4$

Data yang digunakan dalam analisis kurva selektivitas ini adalah panjang cagak (fork length) dan lingkar tubuh (body girth) ikan beloso.

\section{HASIL DAN BAHASAN}

\section{Hasil Tangkapan}

Selama ujicaba JTEDs (21 stasiun), total hasil tangkapan ikan beloso dari masing-masing stasiun bervariasi. Ikan beloso yang tertangkap dan masuk ke kantong jaring (codend) berkisar 0,5-3,5 kg dengan total tangkapan ikan beloso $33,98 \mathrm{~kg}(69,21 \%)$. Sedangkan ikan beloso yang lolos dan tertampung pada cover net berkisar $0,2-1,96 \mathrm{~kg}$ dengan total tangkapan $15,12 \mathrm{~kg}(30,79 \%)$.

Rata-rata pelolosan ikan beloso dari ketiga kisikisi dapat dilihat pada Tabel 1. Berdasarkan pada tabel tersebut, kisi-kisi 10,0 $\mathrm{mm}$ persentase meloloskan ikan beloso lebih tinggi dibandingkan kisi-kisi 17,5 dan $25,4 \mathrm{~mm}$. Tingginya rata-rata persentase pelolosan ikan beloso untuk kisi-kisi 10,0 mm, menunjukkan ukuran ikan yang tertangkap selama ujicoba pengoperasian JTEDs didominansi oleh ikan beloso berukuran kecil yaitu berukuran di bawah lebar celah kisi-kisi JTEDs tersebut. Secara logis, ukuran tubuh ikan beloso yang dapat lolos melalui kisi-kisi JTEDs adalah ikan yang mempunyai nilai rasio tinggi tubuh terhadap ukuran kisi-kisi lebih kecil dari satu atau sama dengan satu $\left(R_{t}<1\right.$ atau $\left.R_{t}=1\right)$. Fenomena tertangkapnya ikan-ikan berukuran kecil (ikan muda) selama uji coba JTEDs sulit dihindari, namun demikian, melalui pemasangan kisi-kisi JTEDs pada jaring arad, peluang lolosnya ikan-ikan berukuran kecil (juvenile) dapat ditingkatkan. Fenomena yang sama dialami dalam penelitian bubu yang dilengkapi celah pelolosan bahwa tertangkapnya bycatch sulit dihindari, namun telah membuktikan ikan-ikan kakap berukuran kecil dapat meloloskan diri melalui perangkap tersebut (Purbayanto et al., 2006).

Secara umum, bahwa dari hasil uji coba JTEDs pada jaring arad dibuktikan ketiga ukuran kisi-kisi JTEDs yaitu kisi-kisi 10,0, 17,5, dan 25,4 mm dapat meloloskan ikan beloso dengan ukuran Lc $<$ Lc ikan beloso yang masuk kantong jaring arad (mini bottom traw).

\section{Jenis Ikan}

Selama uji coba JTEDs jenis ikan hasil tangkapan yang berhasil diidentifikasi 47 famili meliputi ikan, udang, kepiting, cumi-cumi, sotong, dan biota invertebrata lainnya. Ikan beloso (Synodontidae; $19,41 \%$ ) merupakan hasil tangkapan yang paling dominan, diikuti oleh ikan petek (Leiognathus bindus, Leiognathidae; 15,51\%), dan kurisi (Nemipterus spp., Nemipteridae; $12,27 \%$ ).

Jenis ikan beloso yang mendominansi hasil tangkapan jaring arad memberikan informasi yang sama dibanding dengan spesies hasil tangkapan trawl mini di Laut Jawa pada bulan September, Oktober, dan Desember (Hufiadi et al., 2008), trawl di Selat Malaka pada bulan Agustus 2003 (Hufiadi \& Nurdin, 2006) dan hasil tangkapan traw/ di Laut Jawa pada bulan Oktober 2002 (Pujiyati et al., 2007) menunjukkan bahwa ikan beloso tersebar luas dan dapat beradaptasi di berbagai perairan. Ikan beloso adalah salah satu jenis ikan demersal ekonomis penting yang cukup banyak tertangkap dengan alat tangkap yang dioperasikan di dasar perairan seperti trawl dan cantrang (Losse \& Dwiponggo,1977; Beck \& Sudradjat, 1979). Daerah penyebaran ikan beloso meliputi kedalaman 10-60 m dan kebanyakkan terkonsentrasi pada perairan dasar yang berlumpur (Fischer \& Whitehead, 1974).

\section{Ukuran Ikan}

Hasil pengukuran terhadap panjang cagak (fork length), tinggi tubuh (body depth), dan lingkar tubuh (body girth) ikan contoh beloso dapat dilihat pada Tabel 2. Ukuran ikan dibedakan antara ikan yang masuk kantong jaring arad (codend) dan jaring pembungkus JTEDs (cover net) dari masing-masing ukuran kisikisi yaitu ukuran 10,0, 17,5, dan 25,4 mm.

Berdasarkan pada Tabel 1, dapat disimpulkan bahwa rata-rata ukuran ikan contoh dari ketiga perlakuan kisi-kisi JTEDs, yang lolos atau masuk cover net cenderung berukuran lebih kecil dibandingkan dengan rata-rata ukuran ikan yang masuk kantong (codend). Demikian pula berdasarkan pada ukuran kisi-kisi JTEDs, diperoleh bahwa semakin besar ukuran kisi-kisi, rata-rata ukuran contoh ikan (FL) yang lolos atau tertampung pada cover net semakin meningkat. Diungkapkan oleh Fischer \& Whitehead (1974), bahwa ikan beloso memiliki badan memanjang dan silinder, banyak tertangkap pada umumnya berukuran $10-30 \mathrm{~cm}$ dan maksimum mencapai $38 \mathrm{~cm}$. 
Tabel 1. Persentase pelolosan ikan dari tiga kisi-kisi JTEDs

\begin{tabular}{cc}
\hline Kisi-kisi $(\mathbf{m m})$ & Rata-rata \% \\
\hline 10,0 & 52,86 \\
17,5 & 16,13 \\
25,4 & 29,06 \\
\hline
\end{tabular}

Tabel 2.

Rata-rata ukuran contoh ikan yang masuk ke kantong arad (codend) dan JTEDs (cover net) dengan tiga macam ukuran kisi-kisi JTEDs 10,0, 17,5, dan 25,4 mm

\begin{tabular}{|c|c|c|c|c|c|c|c|c|c|c|}
\hline \multirow[b]{2}{*}{ No. } & \multirow{2}{*}{$\begin{array}{c}\text { Perlakuan } \\
\text { JTEDs }\end{array}$} & \multirow[b]{2}{*}{ Jenis } & \multicolumn{4}{|c|}{ Kantong arad (codend) } & \multicolumn{4}{|c|}{ JTEDs (cover net) } \\
\hline & & & $\begin{array}{l}\mathrm{FL} \\
(\mathrm{cm})\end{array}$ & $\begin{array}{l}\text { Tinggi } \\
\text { (cm) }\end{array}$ & $\begin{array}{l}\text { Lingkar } \\
\text { (cm) }\end{array}$ & $\mathbf{n}$ & $\begin{array}{c}\mathrm{FL} \\
(\mathrm{cm})\end{array}$ & $\begin{array}{c}\text { Tinggi } \\
\text { (cm) }\end{array}$ & $\begin{array}{l}\text { Lingkar } \\
\text { (cm) }\end{array}$ & $\mathbf{n}$ \\
\hline 1. & $\begin{array}{l}\text { Kisi-kisi 10,0 } \\
\mathrm{mm}\end{array}$ & Saurida sp. & 12,6 & 1,4 & 4,6 & 141 & 9,9 & 0,9 & 3,4 & 131 \\
\hline 2. & $\begin{array}{l}\text { Kisi-kisi 17,5 } \\
\mathrm{mm}\end{array}$ & Saurida sp. & 11,2 & 1,3 & 4,3 & 187 & 10,3 & 1,0 & 3,5 & 116 \\
\hline 3. & $\begin{array}{l}\text { Kisi-kisi 25,4 } \\
\text { mm }\end{array}$ & Saurida sp. & 13,5 & 1,8 & 5,3 & 88 & 11,4 & 1,2 & 4,3 & 80 \\
\hline
\end{tabular}

\section{Rasio Pelolosan}

Berdasarkan pada ukuran contoh ikan beloso, rasio pelolosan tinggi tubuh (body width) terhadap ukuran kisi kisi JTEDs, dapat dilihat pada Gambar 2. Diprediksikan ukuran ikan beloso dengan tinggi tubuh lebih besar dari ukuran kisi-kisi tidak akan dapat lolos melewati celah kisi kisi JTEDs dan atau ukuran tinggi tubuh yang lebih kecil dari ukuran kisi-kisi akan lolos melewati JTEDs. Namun kenyataan bahwa banyak ukuran dengan rasio tinggi tubuh $\left(R_{t}\right)$ bernilai lebih dari satu $\left(R_{t}>1\right)$ dapat lolos melewati kisi-kisi JTEDs. Hal ini diduga karena sifat tubuh ikan beloso yang lentur memungkinkan ikan dengan ukuran tinggi tubuh yang lebih besar dari lebar kisi-kisi dapat lolos keluar melewati kisi-kisi. Hal tersebut dapat pula terjadi karena kelenturan kisi-kisi yang tidak stabil karena pengaruh mekanika arus. Sebaliknya ukuran rasio tinggi tubuh ikan beloso $\left(R_{t}\right)$ bernilai kurang dari satu $\left(R_{t}<1\right)$ banyak masuk ke dalam kantong. Hal ini dapat terjadi karena ikan yang berenang atau terbawa arus langsung masuk ke bagian kantong jaring tanpa terlebih dahulu kontak dengan perangkat JTEDs, atau dapat terjadi pula di mana saat ikan kontak dengan perangkat JTEDs, posisi badan ikan yang tidak sejajar (melintang) dengan celah kisi-kisi yang memungkinkan ikan tidak dapat lolos dan kemudian masuk ke dalam kantong jaring (codend).

Distribusi frekuensi panjang cagak (FL) ikan beloso yang lolos paling banyak lolos melalui celah kisi-kisi JTEDs pada kisi kisi 10,0, 17,5, dan 25,4 mm adalah berukuran 9,0-10,5 cm. Untuk ikan dalam selang kelas yang sama, kisi-kisi yang efektif meloloskan ikan adalah yang mampu meloloskan ikan dalam jumlah terbanyak. Gambar 3 menunjukkan kisi-kisi 10,0 mm meloloskan ikan terbanyak untuk panjang cagak (FL) $12,5 \mathrm{~cm}$ diikuti oleh kisi-kisi 17,5 dan 25,4 mm. Untuk ikan dengan FL $>12,5 \mathrm{~cm}$, kisi-kisi 25,4 cm meloloskan ikan dalam jumlah terbanyak diikuti kisi-kisi $17,5 \mathrm{~cm}$.

\section{Selektivitas JTEDs}

Selekivitas alat tangkap adalah kemampuan menentukan sasaran dalam menangkap ikan menurut jenis, kelamin, dan ukuran atau kombinasi ketiganya selama proses penangkapan dan memungkinkan semua hasil tangkapan non target diloloskan tanpa cidera (FAO, 1995). Selain itu, dikatakan juga bahwa selektivitas alat tangkap adalah fungsi alat tangkap untuk menangkap ikan yang terbatas pada jenis dan ukuran ikan tertentu pada suatu populasi yang ditemui di daerah penangkapan atau status populasi (Arimoto, 1999; Ferno \& Olsen, 1994).

Kurva selektivitas jaring arad yang dipasangi kisikisi JTEDs terhadap panjang cagak (FL) ikan beloso disajikan pada Gambar 4. Hasil analisis selektivitas menunjukkan bahwa panjang cagak (fork length) ikan beloso pada tingkat seleksi $50 \%\left(\mathrm{FL}_{50 \%}\right)$ untuk kisikisi 10,0, 17,5, dan 25,4 mm masing-masing 11,05 $\mathrm{cm}, 11,92$, dan $13,31 \mathrm{~cm}$. Berdasarkan pada nilai tersebut, kisi-kisi 25,4 mm dapat meloloskan ikan beloso dengan $\mathrm{FL}$ yang lebih besar dibandingkan dengan kisi-kisi 10,0 dan $17,5 \mathrm{~mm}$ pada tingkat selektivitas $50 \%$. Untuk kisi-kisi $17,5 \mathrm{~mm}$ dapat meloloskan ikan beloso dengan ukuran FL sedikit lebih besar dibandingkan kisi-kisi 10,0 mm.

Nilai kemiringan kurva selektivitas (selection span) untuk kisi-kisi 10,0, 17,5, dan 25,4 mm berurutan masing-masing 3,25, 6,38, dan 9,89. Berdasarkan 

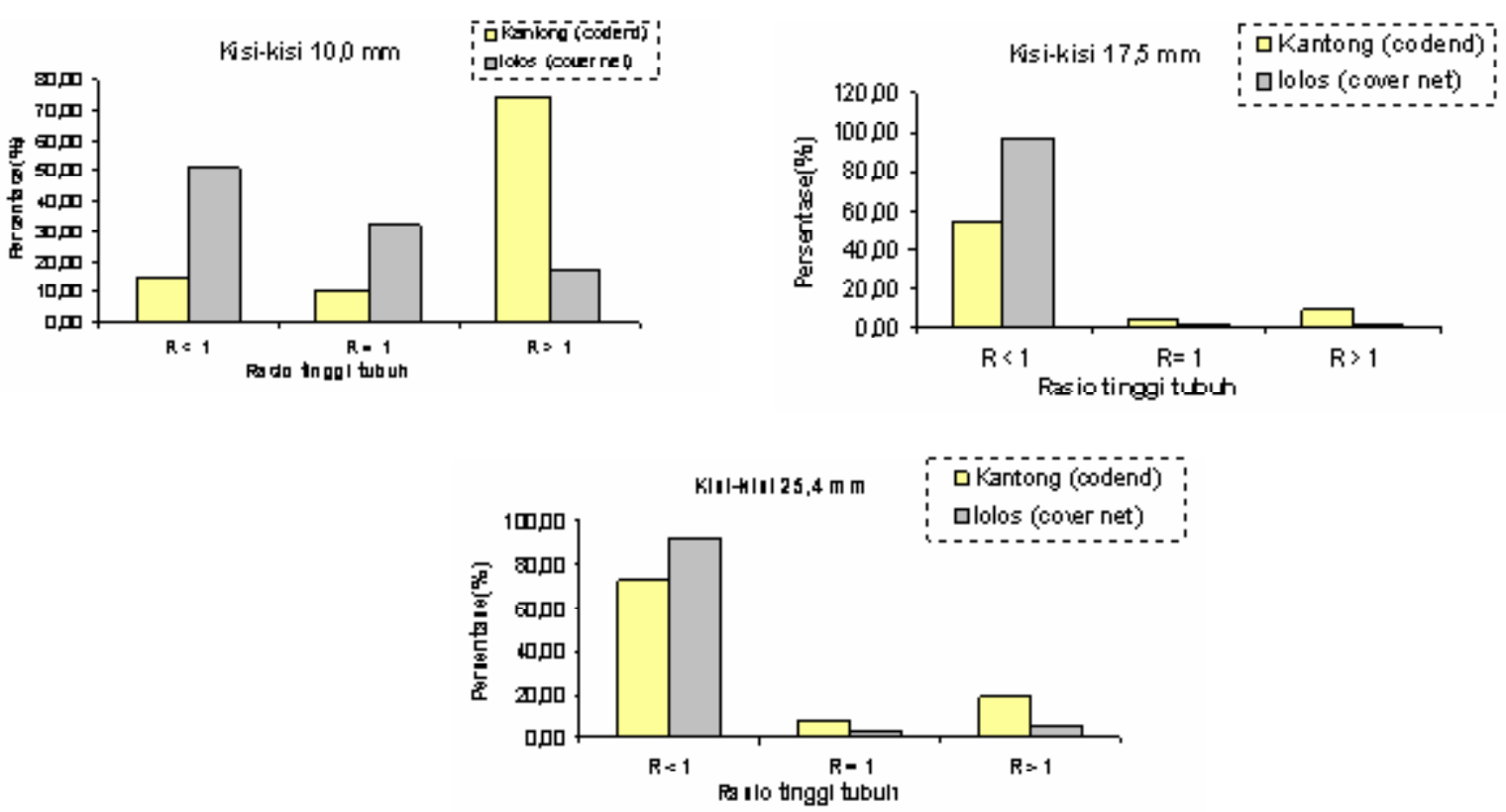

Gambar 2. Pesentase rasio tinggi tubuh ikan beloso untuk kisi-kisi 10,0, 17,5, dan 25,4 mm.

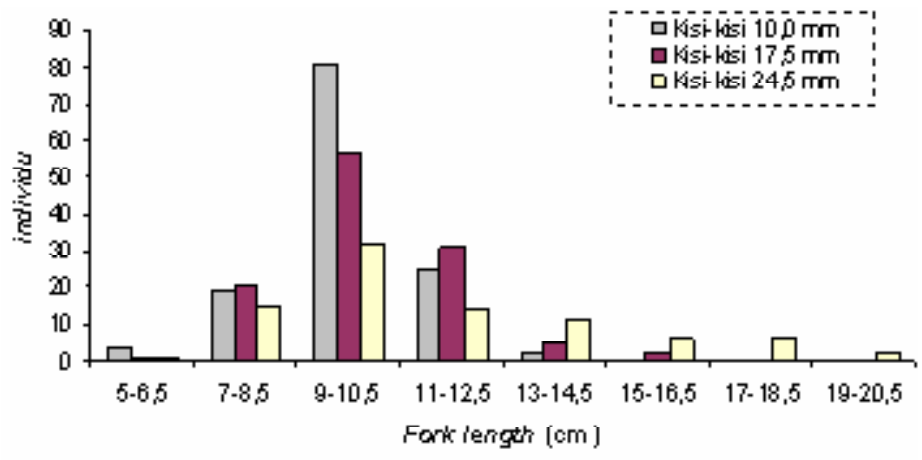

Gambar 3. Histogram jumlah pelolosan ikan menurut ukuran panjang cagak.

pada nilai tersebut menunjukkan bahwa kisi-kisi 25,4 $\mathrm{mm}$ memiliki kemiringan kurva selektivitas yang lebih besar atau lebih landai dibandingkan kisi-kisi 10,0 dan $17,5 \mathrm{~mm}$. Demikian pula kisi-kisi 17,5 mempunyai kemiringan lebih landai dibandingkan kisi-kisi 10,0 $\mathrm{mm}$. Kemiringan kurva sangat menentukan kisaran ukuran ikan yang terseleksi (range of selection) pada tingkat selektivitas $50 \%$ yaitu semakin besar nilai kemiringan kurva, maka kisaran ukuran ikan yang terseleksi semakin lebar (Purbayanto et al., 2006).

Kurva selektivitas jaring arad yang dipasangi JTEDs terhadap lingkar tubuh (body girth) ikan beloso disajikan pada Gambar 5. Hasil analisis selektivitas menunjukkan bahwa lingkar tubuh (body girth) ikan beloso pada tingkat seleksi $50 \%\left(B_{G-}{ }_{50 \%}\right)$ untuk kisikisi 10,0, 17,5, dan 25,4 mm masing-masing 3,91, 3,65 , dan 4,74 cm. Berdasarkan pada nilai tersebut, kisi-kisi 25,4 mm dapat meloloskan ikan-ikan beloso dengan lingkar tubuh yang lebih besar dibandingkan dengan kisi-kisi 10,0 dan $17,5 \mathrm{~mm}$ pada tingkat selektivitas 50\%. Sementara untuk kisi-kisi 10,0 mm dapat meloloskan ikan beloso dengan ukuran BG sedikit lebih besar dibandingkan kisi-kisi 17,5 $\mathrm{mm}$.

Nilai kemiringan kurva selektivitas (selection span) untuk kisi-kisi 10,0, 17,5, dan 25,4 mm berurutan adalah 1,83, 3,19, dan 3,71. Berdasarkan pada nilai tersebut, kisi-kisi 25,4 mm memiliki kemiringan kurva selektivitas yang lebih besar atau lebih landai dibandingkan kisi-kisi 10,0 dan 17,5 mm. Nilai kemiringan kurva selektivitas terhadap ikan beloso sama seperti halnya yang ditunjukkan terhadap panjang cagak dan lingkar tubuh yaitu bahwa kisikisi 25,4 memperoleh kisaran ukuran ikan yang terseleksi lebih lebar dibandingkan dengan kisi-kisi 10,0 dan $17,5 \mathrm{~mm}$ pada tingkat selektivitas $50 \%$.

Berdasarkan pada hasil analisis selektivitas jaring arad yang dipasangi JTEDs terhadap ikan beloso 
diperoleh bahwa ukuran panjang cagak (fork length) dan lingkar tubuh (body girth) pada tingkat seleksi $50 \%\left(F L_{50 \%}\right)$ untuk kisi-kisi $25,4 \mathrm{~mm}$ dapat meloloskan ikan-ikan beloso yang lebih besar dan memiliki kemiringan kurva selektivitas yang lebih besar atau cenderung lebih landai dibandingkan dengan kisi-kisi 10,0 dan 17,5. Berdasarkan pada nilai yang dihasilkan pada tiingkat selektivitas yang sama, berarti bahwa kisi-kisi 25,4 mm paling efektif untuk meloloskan ikan dengan ukuran FL yang lebih besar dibanding kisikisi 10,0, dan 17,5. Sementara berdasarkan pada keragaan kurva selektivitas yang dihasilkan, kisi-kisi 10,0 mm memiliki kemiringan kurva yang terendah, berarti bahwa kisi-kisi 10,0 mm memiliki kisaran ukuran ikan yang dapat diseleksi lebih sempit. Sebagaimana dikatakan oleh Purbayanto et al. (2006), bahwa keragaan selektivitas ukuran celah pelolosan dapat dinilai dari kemiringan kurva (selection span) dan tingkat seleksi pada $\mathrm{L}_{50 \%}\left(\mathrm{FL}_{50 \%}\right)$.

Dari penelitian yang telah dilakukan diperoleh bahwa ukuran Lc (length of first capture) ikan beloso
(Saurida longimanus) yang dominan tertangkap jaring traw/di Laut Jawa berukuran Lc 10,35 cm (Dwiponggo et al., 1986). Penelitian Ernawati (2008) pada bulan Oktober 2006 di Tegal, disimpulkan bahwa ukuran ikan beloso pertama kali matang gonad $\mathrm{Lm} 17,0 \mathrm{~cm}$. Berdasarkan pada hasil penelitian Dwiponggo et al. (1986), bahwa pemasangan JTEDs pada jaring arad untuk ketiga kisi-kisi $(10,0,17,5$, dan 25,4 mm) pada tingkat selektivitas $50 \%$ dapat meloloskan ikan beloso dengan ukuran FL yang yang lebih besar dibandingkan ukuran nilai Lc dari penelitian tersebut. Dengan demikian, pemasangan JTEDs untuk ketiga kisi-kisi $(10,0,17,5$, dan 25,4 mm) dapat meloloskan ikan beloso yang berukuran Lc di bawah ukuran ikan pertama kali dapat ditangkap. Demikian pula kisi-kisi 25,4 mm dapat meloloskan ikan beloso dengan ukuran FL yang lebih besar dari ukuran ikan beloso pertama kali matang gonad $(\mathrm{Lm}=17,0 \mathrm{~cm})$ sebagaimana hasil penelitian Ernawati (2008). Hasil penelitian ini menunjukkan bahwa pemasangan JTEDs pada alat tangkap arad berhasil meloloskan sebagian ikan-ikan yang berukuran lebih kecil dari yang seharusnya

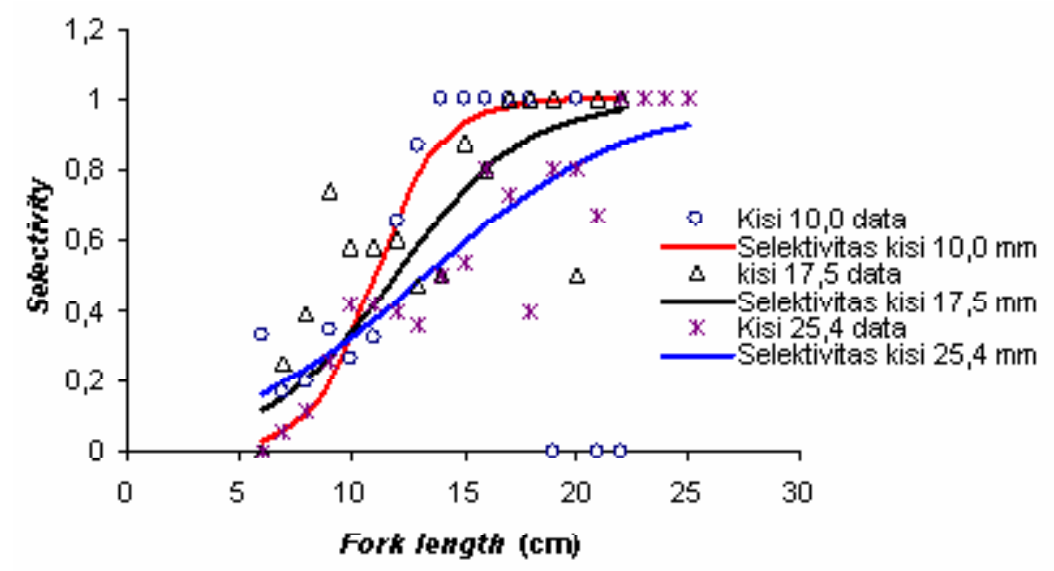

Gambar 4. Kurva selektivitas arad yang dilengkapi JTEDs terhadap ikan beloso.

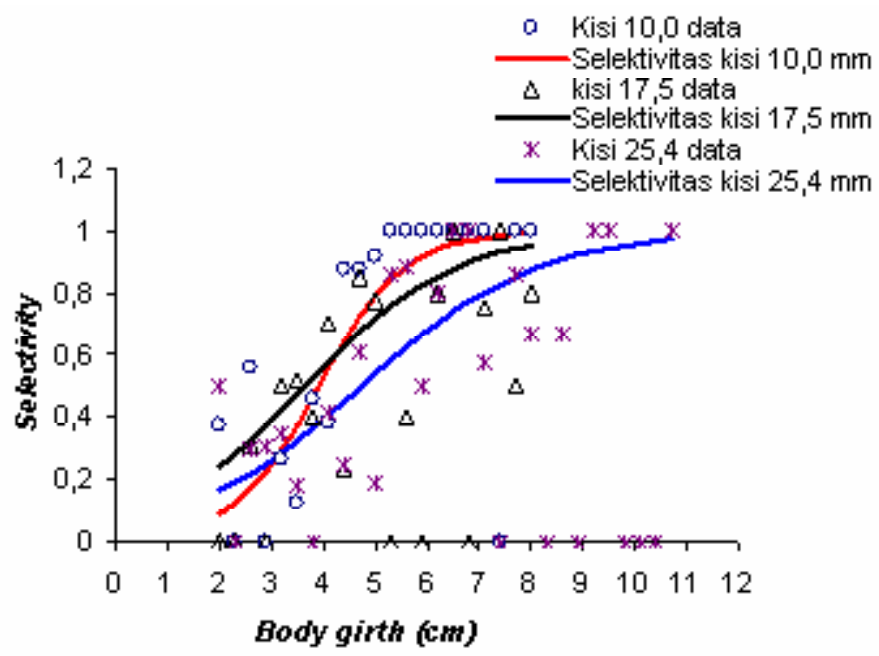

Gambar 5. Kurva selektivitas arad dilengkapi JTEDs terhadap ikan beloso. 
tertangkap. Dengan harapan dapat menunda waktu penangkapan bagi ikan-ikan ukuran kecil atau muda (juvenile) sampai dapat tumbuh besar dan dapat bertelur atau memijah.

\section{KESIMPULAN}

1. Melalui pemasangan kisi-kisi JTEDs pada jaring arad, peluang lolosnya ikan-ikan berukuran kecil (juvenile) dapat ditingkatkan.

2. Selama pengoperasian ikan beloso yang tertangkap dan masuk ke kantong jaring arad (codend) berjumlah 33,98 kg (69,21\%) sementara yang lolos dan tertampung pada cover net berjumlah $15,12 \mathrm{~kg}(30,79 \%)$.

3. Semakin lebar ukuran kisi-kisi JTEDs, cenderung ukuran ikan beloso yang diloloskan semakin besar.

4. Kisi-kisi 25,4 mm lebih efektif meloloskan ikan beloso dengan ukuran fork length $(F L)$ yang lebih besar dibandingkan dengan kisi-kisi 10,0 dan 17,5 $\mathrm{mm}$ pada tingkat selektivitas $50 \%$.

\section{PERSANTUNAN}

Kegiatan dari hasil riset selektivitas unit penangkapan pukat dasar (botton seine net) di utara Jawa, T. A. 2005-2006, di Balai Riset Perikanan LautMuara Baru-Jakarta.

\section{DAFTAR PUSTAKA}

Arimoto, T. 1999. Fish Behaviour for improving Fish Capture Technology. Tokyo University of Fisheries, Japan. 55 pp.

Beck, U. \& A. Sudradjat. 1979. Variation in size and composition of demersal trawl catches from the north coast of Java with estimated growth parameters Pro three importand food fish species. Special Report Contrib of Dem. Fish. Pro. No.71979. LPPL-GTL. 80 pp.

Dwiponggo, A., T. Hariati, S. Banon, M. L. Palomares, \& D. Pauly. 1986. Growth, Mortality, and Recruitment of Commercially Important Fishes and Penaeid Shrimps in Indonesian Waters. RIMF and ICLARM. 91 pp.

Ernawati, T. 2008. Sebaran panjang, pertumbuhan, dan kematangan ikan beloso (Saurida micropectoralis) di perairan utara Jawa. Prosiding Seminar Nasional Tahunan V Hasil Penelitian Perikanan dan Kelautan 2008. Manajemen
Sumber Daya Perikanan. Jurusan Perikanan dan Kelautan. Fakultas Pertanian. Universitas Gadjah Mada. Balai Besar Riset Pengolahan Produk dan Bioteknologi Kelautan dan Perikanan. Badan Riset Kelautan dan Perikanan. Jilid 2. 16: 1-6.

FAO. 1995. Code of Conduct for Responsible Fisheries. FAO. Rome.

Ferno, A. \& S. Olsen. 1994. Marine Fish Behaviour in Capture Abundance Estimation. Fishing News Book. London. 69-81.

Fischer, W. \& P. J. P. Whitehead. 1974. FAO species identification sheet $s$ for fishery purposes. Eastern Indian Ocean (Fishing Area 57) and Western Central Pacific (Fishing Area 71). Rome. FAO. 4 Vols. pag. var.

Hufiadi, Mahiswara, \& E. Nurdin. 2008. Selektivitas kisi-kisi juvenile and trash excluder devices pada alat tangkap trawl mini di perairan utara Jawa. Jurnal Penelitian Perikanan Indonesia. Pusat Riset Perikanan Tangkap. Badan Riset Kelautan dan Perkanan. Jakarta. 14. 4: 353-361.

Hufiadi \& E. Nurdin. 2006. Laju tangkap dan kepadatan stok ikan demersal di perairan sekitar Pulau Berhala, Selat Malaka. Seminar Nasional Perikanan Tangkap. Departemen Pemanfaatan Sumber Daya Perikanan. Fakultas Perikanan dan IImu Kelautan. Institut Pertanian Bogor. Bogor. 128133.

Losse, G. F. \& A. Dwiponggo. 1977. Report on the Java Sea southest monsoon trawl survey JuneDecember 1976. Special Report. Contrib. of Dem. Fesh Pro. No.3-1977. LPPL GTZ. 119 pp.

Pascoe, S. 1997. Bycatch management and the economic of discarding. FAO Fisheries Technical Paper. FAO. Rome. 370: 1-27; 87-96.

Purbayanto, A., R. Wahyu, \& S. Tirta. 2006. Selektivitas bubu yang dilengkapi dengan celah pelolosan terhadap ikan kakap (Lutjanus sp. Bleeker). Gakuryoku. XII. (1): 92-98.

Pujiyati, S., Wijopriono, Mahiswara, B. P. Pasribu, I. Jaya, \& D. Manurung. 2007. Estimasi hambur balik dasar perairan dan sumber daya ikan demersal menggunakan metode hidroakustik. Jurnal Penelitian Perikanan Indonesia. Pusat Riset Perikanan Tangkap. Badan Riset Kelautan dan Perkanan. Jakarta. 145-155. 
Sparre, P., \& S. V. Venema. 1999. Introduksi Pengkajian Stok Ikan Tropis. Organisasi Pangan dan Pertanian Perserikatan Bangsa-Bangsa. FAO. Pusat penelitian dan Pengembangan Perikanan. Badan penelitian dan Pengembangan Pertanian Jakarta. $438 \mathrm{pp}$.
Tokai, T. 1997. Maximum likelihood parameter estimates of a mesh selectivity logistic model through SOLVER on MS-Excel. Bulletin Japan Society Fishery Oceanography. 61: 288-298. 